\title{
Growth performance, productivity and diseases susceptibility of barley varieties in Slovenia within the Cobra project's site comparison
}

\author{
Silva GROBELNIK MLAKAR, Manfred JAKOP, Martina ROBAČER, Martina BAVEC, Franc BAVEC* \\ University of Maribor, Faculty of Agriculture and Life Sciences, Pivola 10, 2311 Hoče, Slovenia
}

\begin{abstract}
Different plant genotypes react differently in different climates. A field experiment was carried out to estimate the growth performance, productivity and diseases susceptibility of spring barley varieties in the Slovenian climate. We received some varieties, mainly of Nordic origin, from the Technical University of Denmark, a COBRA project partner, which were previously tested in estimated future climate in RERAF phytotron. Varieties of the highest grain yield $\left(3,993 \mathrm{~kg} \mathrm{ha}^{-1}\right.$ in 'Evergreen' to $5,146 \mathrm{~kg} \mathrm{ha}^{-1}$ in 'Sebastian') were rather shorter $(58.7 \mathrm{~cm}$ to $67.1 \mathrm{~cm})$ and mostly had the highest specific

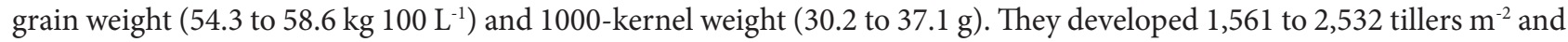
515 to 840 ears $\mathrm{m}^{-2}$ and reached a heading stage between $13^{\text {th }}$ and $25^{\text {th }}$ of May. The tested varieties seem rather insusceptible to most common diseases, but susceptible to cereal leaf beetle attacks.
\end{abstract}

Key words: organic breeding, barley, varieties, productivity, disease susceptibility

\section{INTRODUCTION}

COBRA (Coordinating organic plant breeding activities for diversity) is a Core Organic II project which links 41 partners and is aimed at expanding existing breeding and research activities, with a focus on increasing the use and potential of plant material with a good pest and disease resistance, the ability to react to environmental, especially climatic, variability and climatic change, and that has a high competitiveness against weeds (Cobra div).

Within the project, the role of crop genetic diversity in spring barley has been investigated by the Faculty of Agriculture and Life Sciences (FALS) of the University of Maribor in Slovenia. FALS tested the growth and yield performance, as well as the disease susceptibility of 10 spring barley varieties received from the Technical University of Denmark.

\section{MATERIALS AND METHODS}

Samples of 10 spring barley varieties ('Alliot', 'Brage', 'Brio', 'Evergreen', 'Edvin', 'Jacinta', 'Mari', 'Pallas', 'Sebastian' and 'Tron Sejet') were received in 2015 from the Technical University of Denmark. The varieties 'Brage', 'Brio' and 'Edvin' are 6-row and all others are 2-row sub-type. Varieties have been chosen according to their response in production parameters to a projected future climate, as well as the Slovene climate, and analysed in RERAF phytotron (Ingvordsen et al. 2015).

The experimental site was located at the University $\mathrm{Ag}$ ricultural Centre in Pivola $\left(46^{\circ} 28^{\prime} \mathrm{N}, 15^{\circ} 38^{\prime} \mathrm{E}, 282 \mathrm{~m}\right.$ a.s.l., mean air temperature of the area is $10.7^{\circ} \mathrm{C}$ and annual rainfall around 1,000 mm). The first quarter of 2015 was warm, sunny and with modest rainfall. Spring was warm with a drought, except May which had $160 \mathrm{~mm}$ of rainfall. Warm and dry conditions were predominant in June and July.

A field experiment was carried out on a dystric cambisol of sandy loam texture (good P and K supply, after AL method, slightly acid ( $\mathrm{pH} 5.9), 1.3 \%$ organic matter) and arranged 
in a completely randomized block design. Because a small quantity of seeds had been received, it was conducted in three replications in experimental plots sized $3 \mathrm{~m}^{2}(1 \times 3$ $\mathrm{m})$. After the seedbed preparation, the plots were fertilised with inorganic fertilisers approved for organic production (Hypercorn, $70 \mathrm{~kg} \mathrm{ha}^{-1} \mathrm{P}_{2} \mathrm{O}_{5}$ and Patent kali ${ }^{\oplus}, 40 \mathrm{~kg} \mathrm{ha}^{-1} \mathrm{~K}_{2} \mathrm{O}$ ) and the varieties were sown in mid March $\left(220 \mathrm{~kg} \mathrm{ha}^{-1}\right)$. The side dressing was performed at the EC 31 growth stage in May (Biosol, $32 \mathrm{~kg} \mathrm{~N} \mathrm{ha}^{-1}$ ). A tine weeder was used twice until the EC 31 growth stage was reached.

Varieties were evaluated based on heading date (in May), plant height, tillering, susceptibility to the most prevalent diseases in our condition such as Helminthosporium teres, Rhynchosporium secalis and Ramularia collo-cygni (in June), and on harvest (21. July) grain yield, specific weight, moisture (Aquamatic, Perten), and 1000-kernel weight were assessed. Levels of infestation with diseases and damage caused by Oulema melanopus were assessed according to the protocol of the Agricultural Institute of Slovenia (logarithmic key based on ranking from 1 to 9: 1 is $0 \%$ and 9 is more than $62 \%$ upper part of plants or leaves area infected) as it is used in national variety tests (FURS 2012) carried out at FALS every year.

The obtained results were subjected to analysis of variance (ANOVA) using Statgraphics Centurion (2005) and a comparison of means was performed by the Duncan test (Hoshmand 2006). The results are presented as means \pm standard errors (SEM) of three replications.

\section{RESULTS}

Results describing the growth and yield performance of 10 tested spring barley varieties are presented in Table 1. Among ten varieties, five were ranked into the highest grain yield group (from 3,993 kg ha-1 in 'Evergreen', 4,018 $\mathrm{kg} \mathrm{ha}^{-1}$ in 'Tron Sejet' 4,245 kg ha'-1 in 'Brage', 4,412 $\mathrm{kg} \mathrm{ha}^{-1}$ in 'Alliot' to $5,146 \mathrm{~kg} \mathrm{ha}^{-1}$ in 'Sebastian'). Those varieties are rather shorter (58.7 cm 'Brage' to $67.1 \mathrm{~cm}$ 'Alliot'), have higher specific grain weight (54.3 kg $100 \mathrm{~L}^{-1}$ in 'Tron Sejet' to 58.6 in 'Alliot') and, except 'Brage' (31, $9 \mathrm{~g})$, have higher 1000-kernel weight (34.4 to $40.1 \mathrm{~g})$. Except for the variety 'Sebastian' (2,878 tillers $\mathrm{m}^{-2}$, 952 ears $\left.\mathrm{m}^{-2}\right)$, all other most productive varieties revealed a lower number of tillers and ears (1,561 tillers $\mathrm{m}^{-2}$ and 515 ears $\mathrm{m}^{-2}$ in 'Brage' to 2,532 tillers $\mathrm{m}^{-2}$ and 840 ears $\mathrm{m}^{-2}$ in 'Tron Sejet'). The heading days of the tested varieties were ranked between $13^{\text {th }}$ and $25^{\text {th }}$ of May.

Results revealing disease infestation and damage caused by pests are not significantly affected by the variety (Table 2). Generally, varieties are ratherinsusceptible to Rhynchosporium secalis (values 1.5 to 2.5 in average 1.9 to $2 \%$ upper plant area infected), and medium susceptible to Ramularia collo-cygni (2.0 to 4.0 in average 2.8 to $5 \%$ leaf area infected) and to Helminthosporium teres (values from 3.0 to 5.0, in average 3.7 to $8 \%$ leaf area infected). Oulema melanopus was abundant in all varieties, and the damage was estimated to lie between 7.0 and 8.0 on a 9-point scale (up to $61 \%$ leaf area infested).

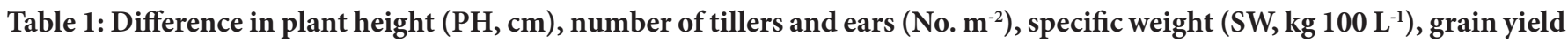
(GY, $\mathrm{kg} \mathrm{ha}^{-1}$, adjusted to $14 \%$ moisture) 1000-kernel weight (TKW, g) and heading date (day in May) among tested barley varieties

\begin{tabular}{|c|c|c|c|c|c|c|c|}
\hline Variety & $\mathrm{PH}(\mathrm{cm})$ & $\begin{array}{l}\text { No. tillers } \\
\left(\text { per } \mathrm{m}^{2}\right)\end{array}$ & $\begin{array}{l}\text { No. ears } \\
\left(\text { per } \mathrm{m}^{2}\right)\end{array}$ & $\begin{array}{c}\text { SW } \\
\left(\operatorname{kg~} 100 \mathrm{~L}^{-1}\right)\end{array}$ & $\begin{array}{c}\mathrm{GY} \\
\left(\mathrm{kg} \mathrm{ha}^{-1}\right)\end{array}$ & TKW (g) & $\begin{array}{c}\text { Heading } \\
\text { (May) }\end{array}$ \\
\hline ANOVA & $* * *$ & $* * *$ & $* * *$ & $* *$ & $* *$ & $* *$ & $* * *$ \\
\hline 'Alliot' & $67.1 \pm 0.12 \mathrm{~d}$ & $1,996 \pm 52.6 \mathrm{~d}$ & $656 \pm 22.6 \mathrm{~d}$ & $58.6 \pm 0.2 \mathrm{ab}$ & $4,412 \pm 554.6 \mathrm{ab}$ & $34.4 \pm 0.58 \mathrm{abc}$ & 13.d \\
\hline 'Pallas' & $70.7 \pm 0.07 c$ & $3,024 \pm 3.8 \mathrm{a}$ & $1,008 \pm 2.2 \mathrm{a}$ & $61.6 \pm 3.5 \mathrm{a}$ & $3,130 \pm 56.2 \mathrm{cde}$ & $36.1 \pm 0.37 \mathrm{ab}$ & 21.b \\
\hline 'Mari' & $58.1 \pm 0.06 \mathrm{j}$ & $1,379 \pm 46.5 \mathrm{e}$ & $455 \pm 16.0 \mathrm{e}$ & $59.76 \pm 0.5 \mathrm{ab}$ & $3,892 \pm 427.3 \mathrm{bcde}$ & $38.1 \pm 2.35 \mathrm{a}$ & 15.c \\
\hline 'Brio' & $78.6 \pm 0.10 \mathrm{a}$ & $1,801 \pm 58.6 \mathrm{~d}$ & $596 \pm 20.7 d$ & $43.06 \pm 3.5 c$ & $2,920 \pm 385.5 \mathrm{de}$ & $28.7 \pm 0.17 \mathrm{~d}$ & 25.a \\
\hline 'Tron Sejet' & $75.4 \pm 0.12 b$ & $2,532 \pm 15.6 c$ & $840 \pm 4.2 \mathrm{c}$ & $54.3 \pm 2.0 \mathrm{ab}$ & $4,018 \pm 324.9 \mathrm{abcd}$ & $35.7 \pm 0.57 \mathrm{abc}$ & $22 . b$ \\
\hline 'Sebastian' & $60.6 \pm 0.09 \mathrm{~g}$ & $2,878 \pm 132.3 \mathrm{ab}$ & $952 \pm 44.7 \mathrm{ab}$ & $57.1 \pm 0.8 \mathrm{ab}$ & $5,146 \pm 425.8 \mathrm{a}$ & $37.1 \pm 0.53 \mathrm{ab}$ & 15.c \\
\hline 'Jacinta' & $59.5 \pm 0.17 \mathrm{~h}$ & $2,732 \pm 51.5 b c$ & $902 \pm 17.2 b c$ & $52.4 \pm 2.7 \mathrm{~b}$ & $2,7266 \pm 237.5 \mathrm{e}$ & $34.7 \pm 0.67 \mathrm{abc}$ & 15.c \\
\hline 'Evergreen' & $64.4 \pm 0.18 \mathrm{f}$ & $2,552 \pm 26.7 c$ & $837 \pm 5.8 c$ & $55.3 \pm 3.3 \mathrm{ab}$ & $3,993 \pm 37.9 \mathrm{abcd}$ & $40.1 \pm 3.48 \mathrm{a}$ & 24.a \\
\hline 'Edvin' & $65.1 \pm 0.03 \mathrm{e}$ & $1,879 \pm 44.8 \mathrm{~d}$ & $620 \pm 13.7 d$ & $53.3 \pm 0.8 \mathrm{~b}$ & $3,744 \pm 264.0 \mathrm{bcde}$ & $30.2 \pm 0.03 c d$ & $20 . b$ \\
\hline 'Brage' & $58.7 \pm 0.15 \mathrm{i}$ & $1,561 \pm 91.8 \mathrm{e}$ & $515 \pm 31.4 \mathrm{e}$ & $52.7 \pm 0.6 b$ & $4,245 \pm 589.7 \mathrm{abc}$ & $31.9 \pm 3.50 \mathrm{bcd}$ & 14.cd \\
\hline
\end{tabular}

Varieties ranked as most productive are in bold

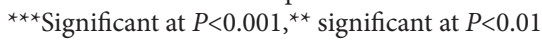

${ }^{\mathrm{a}-\mathrm{i}}$ Mean values $( \pm$ SEM) followed by different letters within a column are significantly

different (Duncan, $\alpha=0.05$ ) 
Table 2: Spring barley varieties assessed for susceptibility to most common diseses and cereal leaf beetle infestation $(O$. melanopus)

\begin{tabular}{|l|c|c|c|c|}
\hline Variety & H. teres & R. secalis & R. collo-cygni & O. melanopus \\
\hline ANOVA & n.s. & n.s. & n.s. & n.s. \\
\hline 'Alliot' & $5.0 \pm 0.0$ & $2.5 \pm 0.5$ & $2.0 \pm 0.0$ & $7.5 \pm 0.5$ \\
\hline 'Pallas' & $4.5 \pm 0.5$ & $2.5 \pm 0.5$ & $3.0 \pm 1.0$ & $7.5 \pm 0.5$ \\
\hline 'Mari' & $4.5 \pm 0.5$ & $1.5 \pm 0.5$ & $3.0 \pm 0.0$ & $7.0 \pm 1.0$ \\
\hline 'Brio' & $3.5 \pm 0.5$ & $2.0 \pm 0.0$ & $2.0 \pm 0.0$ & $7.5 \pm 0.5$ \\
\hline 'Tron Sejet' & $3.0 \pm 1.0$ & $1.5 \pm 0.5$ & $2.0 \pm 0.0$ & $8.0 \pm 0.0$ \\
\hline 'Sebastian' & $3.5 \pm 0.5$ & $1.5 \pm 0.5$ & $3.5 \pm 0.5$ & $8.0 \pm 0.0$ \\
\hline 'Jacinta' & $4.0 \pm 1.0$ & $2.0 \pm 1.0$ & $3.0 \pm 1.0$ & $7.5 \pm 0.5$ \\
\hline 'Evergreen' & $2.5 \pm 0.5$ & $2.0 \pm 0.0$ & $2.5 \pm 0.5$ & $7.5 \pm 0.5$ \\
\hline 'Edvin' & $3.5 \pm 0.5$ & $1.5 \pm 0.5$ & $3.0 \pm 0.0$ & $7.5 \pm 0.5$ \\
\hline 'Brage' & $3.0 \pm 1.0$ & $2.0 \pm 0.0$ & $4.0 \pm 0.0$ & 7.5 \\
\hline Average & 3.7 & 1.9 & 2.8 & 0.5 \\
\hline
\end{tabular}

Varieties ranked as most productive are in bold n.s. - non significant

\section{CONCLUSIONS}

Within the COBRA project, the role of crop genetic diversity in spring barley has been investigated for Slovene conditions. Ten spring barley varieties of Nordic origin were tested on their growth performance, productivity and disease susceptibility. Considering the obtained results, some varieties have shown the potential for organic production, however, further evaluation and additional comparison with the most used domestic varieties is planned.

\section{Acknowledgements}

The presented results are an output of the research project COBRA, funded by the Slovenian Ministry of Agriculture, Forestry and Food under CORE ORGANIC II.

\section{REFERENCES}

1. Cobra div - Coordinating Organic Plant Breeding Activities for Diversity. [http://www.cobra-div.eu/], accesed January 11, 2016.

2. FURS (Phytosanitary Administration of the Republic of Slovenia). Assessment of Value for Cultivation and Use of Agricultural Plant Varieties. FURS, Ljubljana, 2012.

3. Hoshmand AR. Design of Experiments for Agriculture and the Natural Sciences, 2nd ed. Chapman \& Hall/CRC, Boca Raton, FL, 2006.

4. Ingvordsen $\mathrm{CH}$, Backes $\mathrm{G}$, Lyngkjær MF, Peltonen-Sainio P, Jensen JD, Jalli M, Jahoor A, Rasmussen M, Mikkelsen TN, Stockmarr A, Jørgensen RB. Significant decrease in yield under future climate conditions: Stability and production of 138 spring barley accessions. Eur. J. Agron. 2015; 63: 105-113.

5. Statgraphics ${ }^{\circledR}$ (Release Centurion XV) StatPoint, Inc., 2005. 


\section{Rast, produktivnost in občutljivost na bolezni sort jarega ječmena preskušanih v okviru projekta COBRA v Sloveniji}

\section{IZVLEČEK}

Odziv na različne podnebne razmere je genotipsko specifičen. V poljskem poskusu smo na sortah jarega ječmena ocenjevali rast, višino pridelka in občutljivost na bolezni v slovenskih pridelovalnih razmerah. Sorte ječmena, predvsem nordijskega izvora, smo prejeli od partnerske institucije Technical University iz Danske, ki je sodelovala v projektu COBRA. Vse sorte so bile predhodno preskušane $\mathrm{v}$ fitotronu RERAF, v klimatskih razmerah, ki simulirajo pričakovane podnebne razmere v prihodnosti. Skupina sort z značilno najvišjimi pridelki (med $3.993 \mathrm{~kg} \mathrm{ha}^{-1}$ pri 'Evergreen' in $5.146 \mathrm{~kg} \mathrm{ha}^{-1}$ pri sorti 'Sebastian'), so bile značilno nižje $(58,7 \mathrm{~cm}$ do $67,1 \mathrm{~cm})$ in so imele med preskušanimi sortami v večini najvišjo hektolitrsko maso (54,3-58,6 kg $\left.100 \mathrm{~L}^{-1}\right)$ ter maso 1000-zrn (30,2-37,1 g). Razvile so med 1.561 in $2.532 \mathrm{~m}^{-2}$ stranskih poganjkov in med 515 in $840 \mathrm{~m}^{-2}$ poganjkov s klasom. Razvojno fazo klasenje so sorte dosegle med 13. in 25. majem. Preskušane sorte so bile na najpogostejše bolezni ječmena precej neobčutljive, vendar dovzetne na napad žitnega strgača.

Ključne besede: ekološko žlahtnjenje, ječmen, sorte, produktivnost, občutljivost na bolezni 